\title{
Wokół intuicjonizmu metaetycznego Mariana Przełęckiego
}

\author{
Anna Jedynak \\ (Uniwersytet Warszawski, Instytut Filozofii)
}

\section{Intuicjonizm Przełęckiego}

Metaetyczne poglądy Mariana Przełęckiego miały trojakie źródło: po pierwsze - jego własne intuicje moralne. Po drugie - refleksję nad potocznym dyskursem etycznym. Po trzecie i być może najistotniejsze - jego własne indukcjonistyczne poglądy na poznanie naukowe. Choć bowiem odróżniał on etykę od nauki, poznanie moralne modelował według swojej wizji poznania w naukach empirycznych. Płynące z tych źródeł przekonania złożyły się na Przełęckiego metaetyczny obiektywizm, kognitywizm i intuicjonistyczny indukcjonizm ${ }^{1}$.

Za główną inspirację swoich własnych przekonań moralnych uważał etykę ewangeliczną, choć zarazem dystansował się od ewangelicznej metafizyki. Swoje stanowisko nazywał „chrześcijaństwem niewierzących”. Za główny, jeśli nie jedyny motor i wyróżnik moralnego postępowania uważał altruizm, troskę o innych, gotowość przedłożenia cudzych potrzeb ponad własne i bezinteresowne działanie dla dobra bliźnich. Działania uważane przez niektórych za chwalebne, jak dążenie do własnej doskonałości moralnej, pogarda dla grzeszników czy odwet na krzywdzicielach już się w tej formule nie mieszczą. Doskonałość może, zdaniem Przełęckiego, być jedynie ubocznym skutkiem altruistycznych działań, lecz celowe do niej dążenie jest przeciwskuteczne, gdyż jako motyw działania

\footnotetext{
Pojęcia te objaśnione zostaną nieco dalej.
} 
wysuwa się ona na plan pierwszy, ponad autentyczną troskę o innych, którą może przytłumić. Z kolei grzesznik potrzebuje współczucia i pomocy, a nie pogardy, odwet zaś nie tylko nie pomoże krzywdzicielowi zmienić postawy, lecz może wzmacniać antagonizm².

Zauważył Przełęcki, że użytkownicy języka potocznego, wypowiadając oceny, przydają im obiektywny sens. Twierdząc, że jakiś czyn jest dobry czy szlachetny, nie odnoszą się do siebie ani swoich postaw wobec tego czynu, lecz do niego samego i jego cech. Twierdzenia te mówią w ich przekonaniu coś o rzeczywistości, mogą być prawdziwe-lub-fałszywe, a o ich prawdzie-lub-fałszu możemy się wypowiadać w uzasadniony sposób. Przekonując w tym kontekście o obiektywnym sensie predykatów wartościujących, powołał się Przełęcki na pewne konsekwencje teoriomodelowej koncepcji prawdy, pozwalające nadać wartościującym predykatom ten sam status, co i opisowym, zwykle interpretowanym obiektywnie. Charakterystyczny w przyjętym języku sposób rozumienia jednych i drugich pozwala dla każdego predykatu - czy to opisowego, czy wartościującego - wyróżnić trojakiego rodzaju elementy: należące do jego denotacji, nienależące do denotacji i mieszczące się w obszarze nieostrości. Predykaty wartościujące różniłyby się od opisowych tylko większym stopniem nieostrości. Jeśli zatem metaetyk chce sprawozdawczo, a nie projektująco definiować dobro moralne, winien - zdaniem Przełęckiego - uszanować potoczny sens, w jakim predykaty oceniające funkcjonują. Obserwacja ta przydała mocy metaetycznemu obiektywizmowi i kognitywizmowi Przełęckiego.

Przez wiele lat zajmował się Przełęcki logiką i metodologią nauk empirycznych. Rekonstruował stosowane w tych naukach procedury, sytuując się w tradycji liberalnego empiryzmu logicznego i indukcjonizmu. Jego model uprawiania nauk empirycznych przedstawia się mniej więcej tak:

Podstawę tych nauk stanowią zdania obserwacyjne, weryfikowane w drodze bezpośredniej obserwacji. Niektóre z nich bywają uznane, choć są fałszywe, a jest tak $\mathrm{z}$ powodu zawodności poznania bezpośredniego (ze szczególnym uwzględnieniem złudzeń zmysłowych). Do praw ogólnych prowadzą indukcyjne uogólnienia zdań jednostkowych. Ponieważ indukcja jest wnioskowaniem zawodnym, pojawia się tu druga droga, jaką do nauk empirycznych dostać się może fałsz. I jest jeszcze trzecia, związana $\mathrm{z}$ użyciem terminów teoretycznych,

M. Przełęcki, Protest przeciw krzywdzie czy pomoc krzywdzonemu?, w: tegoż, O rozumności i dobroci, Wydawnictwo Naukowe Semper, Warszawa 2002, s. 164-167. 
formułowaniem teorii i wyjaśnianiem teoretycznym. Znaczenie terminów teoretycznych charakteryzowane jest przez ich związki z terminami obserwacyjnymi. Scharakteryzował Przełęcki różne typy postulatów znaczeniowych dla terminów teoretycznych, lecz zawsze kształt tych postulatów pozostawia terminom teoretycznym mniejszy lub większy margines niedookreślenia. Wskutek tego teorie okazują się niedodeterminowane empirycznie: zawierają naddatek informacyjny ponad to, co mieści się w granicach obserwacji. Nie wynikają z żadnych obserwacji, choć na ich podstawie obserwacje można przewidywać. Mimo prawdziwości zdań obserwacyjnych, przewidzianych na bazie teorii i potwierdzających ją w ten sposób, w naddatku tym może kryć się fałsz. Prawa czy teorie nauk empirycznych ulegają odwołaniu, gdy fałszywe okazują się pewne nowe, poczynione na ich podstawie predykcje.

Nie znalazły się w koncepcji Przełęckiego pewne wątki wykraczające już poza logiczny empiryzm, jak na przykład zarzucenie dychotomii: analityczne/syntetyczne albo holizm, albo teoretyczne skażenie obserwacji, prowadzące ostatecznie do zarzucenia dychotomii teoria/obserwacja. Obserwacja jest u niego podstawą, źródłem i ostatecznym probierzem prawdziwości teorii naukowych czy poszczególnych praw, prawa zaś i teorie wspierają się na bazie obserwacji i są względem niej wtórne.

Echa tego właśnie modelu odnajdujemy w Przełęckiego poglądach na poznanie moralne. Jednak jego zdaniem, mimo wielu podobieństw zachodzących między poznaniem dotyczącym empirii a poznaniem moralnym, choć to pierwsze może zakwalifikować się do nauki - drugie granicy naukowości nigdy nie przekracza. Przyjrzyjmy się temu bliżej.

Źródłem bezpośredniego poznania moralnego jest według Przełęckiego uczucie. Poszedł tu za Ajdukiewiczem (który mówił w analogicznym kontekście o uczuciu, sumieniu czy aprobacie moralnej) i za Elzenbergiem (który mówił o intuicji). Jednostkowe oceny, dotyczące poszczególnych czynów, mają być właśnie dyktowane naszą intuicyjną/uczuciową reakcją na te czyny. Pozytywna reakcja prowadzi do dodatniej oceny, a negatywna - do ujemnej. Uczucie pozwala rozpoznawać wartości. Właśnie: rozpoznawać, a nie: kreować. Wartości bowiem przysługują rzeczom obiektywnie, niezależnie od tego, czy są przedmiotem czyjegokolwiek oglądu i refleksji, podobnie jak przysługują rzeczom ich cechy empiryczne, niezależne od czyichkolwiek spostrzeżeń. Na przykład, przedmiot jest czerwony sam w sobie, nie zaś wskutek tego, że obserwator doznaje wrażenia 
czerwieni. Podobnie jak prawdziwości zdań spostrzeżeniowych nie można definiować, odwołując się do spostrzeżeń, tak samo prawdziwości ocen nie można definiować, odwołując się do uczuć. Nie wartość przedmiotu bierze się bowiem z reakcji uczuciowej odbiorcy, lecz przeciwnie: reakcja uczuciowa odbiorcy bierze się z wartości przedmiotu. Spostrzeżenia i uczucia służyć mogą jako kryteria prawdziwości opisów czy ocen, lecz nie - jako ich definicyjna podstawa. Reakcje odbiorcy i ich werbalizacja są bowiem wtórne względem obiektywnych realiów. Zarówno zmysły, jak i intuicja są omylne, zawodne, i mogą czasem dawać fałszywe świadectwo co do cech rzeczy lub ich wartości. (Do tego wątku jeszcze wrócimy).

Intuicję moralną uważał Przełęcki za aposterioryczną, dotyczącą jednostkowych, konkretnych czynów, a nie aprioryczną, dotyczącą od razu ogólnych, abstrakcyjnych zasad. Do zasad moralnych można bowiem dojść dopiero w drodze uogólnienia jednostkowych ocen, podobnie jak w nauce, gdzie dochodzi się do zasad empirycznych wskutek uogólnień jednostkowych zdań obserwacyjnych.

Intuicyjne reakcje uczuciowe są zatem jednostkowe i wyrażają się w jednostkowych ocenach poszczególnych czynów, które były źródłem owych reakcji. Aby jednak można było uogólnić je do postaci zasad etycznych, potrzebne jest uchwycenie wspólnych cech działań, budzących taką samą reakcję uczuciową. Jak inaczej można by wysłowić zasadę? Chyba tylko przez enumerację poszczególnych działań, które jawiłyby się jako przypadkowa zbieranina. A zasada straciłaby wtedy ogólny sens i walor. Ogólna wizja etyczna, prezentująca jakiś porządek aksjologiczny, wymaga praw ogólnych, w których podlegające ocenom czyny ujęte są również ogólnie, ze względu na wspólne im cechy.

Zarówno poznanie empiryczne, jak i moralne przebiegać może bezpośrednio lub pośrednio. $\mathrm{W}$ wypadku tego pierwszego poznanie bezpośrednie znajduje wyraz w jednostkowych opisach, zaczerpniętych wprost ze świadectwa zmysłów. Poznanie pośrednie zaś reprezentują albo same prawa (uzyskane ze świadectw wskutek zastosowania odpowiednich rozumowań), albo wydedukowane $\mathrm{z}$ nich pewne obserwowalne fakty, które jednak przedmiotem naszej obserwacji nie były. Wiemy o nich pośrednio, dzięki zasadom i pracy myślowej. Podobnie jest w poznaniu moralnym: można albo sformułować jednostkową ocenę jakiegoś czynu na podstawie własnej, bezpośredniej reakcji uczuciowej, albo też powoływać się na sformułowane na podstawie jednostkowych ocen prawa ogólne, repre- 
zentujące poznanie pośrednie, i ewentualnie wywodzić z nich inne jednostkowe oceny, niewymagające już oparcia na reakcjach uczuciowych.

Jednak zarówno w poznaniu empirycznym, jak i moralnym, ostateczną instancją pozostają bezpośrednie świadectwa - wszak to $\mathrm{z}$ nich wywodzą się zasady, czy to empiryczne, czy etyczne. I właśnie te świadectwa pozwalają w razie potrzeby uchylić wcześniej przyjęte prawa. W poznaniu empirycznym wydedukowane z przyjętej zasady predykcje mogą okazać się fałszywe. Dzieje się tak na ogół wtedy, gdy poszerza się jakościowo obszar dostępnego doświadczenia: zasada wydawała się dobrze potwierdzona w pewnym wąskim obszarze, lecz wraz z jego poszerzeniem przestaje się „sprawdzać”. Rzeczą naturalną i praktykowaną jest wtedy uchylenie takiego prawa lub przynajmniej ograniczenie zasięgu jego stosowalności. Podobnie w poznaniu moralnym: pewien czyn, chwalebny i zalecany w myśl jakiejś zasady, może wzbudzić czyjś zdecydowany, motywowany uczuciowo sprzeciw. I podobnie jak w poznaniu empirycznym, dzieje się tak raczej w sytuacjach nowych, niewziętych pod uwagę przy uogólnianiu do postaci zasady uprzednich jednostkowych ocen. Skłania to do rewizji zasady lub przynajmniej do ograniczenia jej zasięgu.

Swoją koncepcję metaetyczną (której zręby zaczerpnął od Ajdukiewicza) nazwał Przełęcki intuicjonistycznym indukcjonizmem, gdyż intuicję miał za źródło bezpośredniego, jednostkowego poznania moralnego, indukcję zaś - za niezbędną w poznaniu moralnym ogólnym i pośrednim. Mając wartości - jak i empiryczne cechy rzeczy - za istniejące realnie, a wiedzę o nich za wyrażalną w zdaniach prawdziwych-lub-fałszywych, deklarował się jako obiektywista i kognitywista metaetyczny. Wbrew emotywistom przypisywał predykatom wartościującym sens obiektywny, a sądom wartościującym walor poznawczy. Wbrew naturalistom upominał się o autonomię świata wartości względem faktów empirycznych.

W podobny sposób interpretował powody odwoływalności praw nauk empirycznych i zasad moralnych. I zmysły fizyczne, i intuicja moralna są zawodne, zatem już w punkcie wyjścia w obu typach poznania może pojawić się fałsz. Nadto i opisy, i oceny posługują się predykatami nieostrymi. A tam, gdzie orzeka się o pewnych przedmiotach predykaty nieostre, łatwiej o błąd. Bywają one różnie doprecyzowane, stąd zawierającemu je językowi odpowiada nie jeden tylko model właściwy, lecz rodzina takich modeli. Zdanie jest prawdziwe, gdy jest spełnione w każdym modelu właściwym (tj. przy najmocniejszej interpretacji wy- 
stępujących w nim predykatów nieostrych); jest fałszywe, gdy nie jest spełnione w żadnym modelu właściwym (tj. przy najsłabszej interpretacji występujących w nim predykatów nieostrych); gdy zaś spełnione jest w pewnych, lecz nie wszystkich modelach właściwych - jest nieokreślone semantycznie i prawdziwościowo. A użytkownicy języka, kierowani indywidualnym poczuciem semantycznym, mogą jednak próbować rozstrzygać takie zdania - stąd dodatkowe furtki dla fałszu. Dalej, fałsz może wkraść się przy uogólnieniach, wprowadzających naddatek informacyjny w stosunku do wyjściowej bazy, złożonej ze zdań jednostkowych.

Mimo tych wszystkich analogii etyka nie przekracza w ujęciu Przełęckiego granic nauki (w czym nie jest zresztą odosobniony). A to dlatego, że predykaty oceniające uważa za daleko bardziej niedookreślone od opisowych, intuicję moralną zaś za znacznie bardziej zawodną i niepewną od zmysłów fizycznych. Przytacza przykłady notorycznych rozbieżności w ocenach moralnych, których to rozbieżności nie uważa jednak za przekonujący argument na rzecz subiektywizmu. Pokazuje środki zaradcze: na przykład, daleko ostrzejsze od klasyfikacyjnych predykatów oceniających (jak moralnie dobry) wydają mu się analogiczne predykaty porównawcze (jak moralnie lepszy). Zatem aby zaradzić niedogodnościom etyki, spowodowanym przez nieostrość predykatów oceniających, radzi Przełęcki stosować je w wersji raczej komparatywnej niż klasyfikacyjnej.

Porada ta może mieć zresztą także inny, dodatkowy powód. Opowiadał się Przełęcki za etyką nie nakazów, lecz preferencji. Zamiast ostro odgradzać czyny nakazane od indyferentnych, lepiej jest uszeregować je na skali według stopnia naszej intuicyjnej aprobaty moralnej, jaką budzą. I zamiast wymagać od wszystkich ścisłego przestrzegania arbitralnie wyznaczonych nakazów, lepiej zachęcać, aby każdy określił na tej skali sam dla siebie - według swoich sił, możliwości, wrażliwości i poczucia ważności spraw - obszar obejmujący czyny, które będzie realizował. W szczególności, zdaniem Przełęckiego, nie można bohaterstwa uważać za obowiązek, choć można i trzeba wysoko je cenić czy podziwiać. Jego etyka preferencji pozostaje $\mathrm{w}$ zgodzie zarówno $\mathrm{z}$ jego ukierunkowaniem na porównawcze predykaty oceniające, jak i z jego przekonaniem, że w kwestii moralności indywidualne przypadki bardzo się między sobą różnią, są wielorako uwarunkowane i dlatego trudno tam o formułowanie bezdyskusyjnych, bezwyjątkowych powinności.

$\mathrm{Na}$ szczeblu zasad etyka jest również w większym stopniu zawodna od nauk empirycznych. Pominąwszy już zawodność samej indukcji, poznanie pośrednie 
dziedziczy i multiplikuje niedoskonałość i niepewność poznania bezpośredniego, a to ostatnie, wyrażone w obszarze etyki w formie jednostkowych ocen, jest szczególnie dalekie od consensu. Właśnie ze względu na szczególną zawodność i niepewność poznania moralnego wyłączył je Przełęcki z obszaru nauki. Ale uwaga: naukowość okazuje się tu sprawą stopnia, a nie jakości. A skoro tak, to i samą „naukowość” można by uznać za pojęcie nieostre.

Choć nienaukowa, może być jednak etyka zdaniem Przełęckiego uprawiana racjonalnie. Spełnia ona dwa podstawowe, przyjęte w Szkole Lwowsko-Warszawskiej, a podzielane przez niego kryteria racjonalności: komunikowalność i intersubiektywną sprawdzalność. Nadto może - w zależności od tego, jak jest uprawiana - spełniać dodatkowe, również przyjęte w Szkole pragmatyczne kryterium, w myśl którego stopień pewności, z jaką żywione jest dane przekonanie, ma być dostosowany do stopnia jego uzasadnienia. Można zatem racjonalnie rozważać kwestie etyczne, jeśli wyniki tych rozważań przyjęte będą z należytą dozą ostrożności, w stopniu nieprzekraczającym siły zastosowanej argumentacji.

Do antidotów, mających neutralizować w jakimś stopniu wielką niepewność rozstrzygnięć etycznych, zaliczył Przełęcki przyjęcie warunków, jakie muszą być spełnione, aby ocena moralna była wiarygodna. Za najważniejsze bowiem stojące przed intuicjonizmem wyzwanie uważał pytanie o powody notorycznej rozbieżności ocen moralnych. Aby na nie odpowiedzieć, zaadaptował dla potrzeb intuicjonizmu naturalistyczną teorię idealnego obserwatora i zbliżoną do niej emotywistyczną metodę kontrolowanej postawy. Koncepcje te pokazują, że nie wszelkie oceny moralne są trafne, lecz tylko niektóre, wydane w określonych warunkach, a do tych należy np. bezstronność obserwatora czy jego dokładna wiedza o wszystkich istotnych okolicznościach, np. o motywacji sprawcy. Naturaliści chcieli w ten sposób zdawać sprawę z sensu terminów moralnych, a emotywiści - wskazać kryterium słuszności postaw moralnych. Przełęcki zaś chciał zdać sprawę z rozbieżności ocen: stąd mianowicie ona się bierze, że nie zawsze wszystkie wspomniane warunki są spełnione. A tylko wtedy, gdy są spełnione, reakcja uczuciowa jest miarodajna.

Ważką część pracy etyka stanowi uogólnienie jednostkowych ocen do postaci zasad, które musi być poprzedzone znalezieniem wspólnych cech ocenianych tak samo czynów. Ogólne prawo, przyznające określoną wartość owym czynom, odwoływać się ma właśnie do ich wspólnych cech i przyjmować te cechy jako podstawę uogólnienia. Znalezienie tych cech nie wymaga, zdaniem Przełęckie- 
go, szczególnej inwencji ani pracy koncepcyjnej. Jest to zwykła, sprawozdawcza praca, a jej rezultaty mają być weryfikowane empirycznie. Uznał Przełęcki, że wspólną cechą tych czynów, które budzą jego intuicyjną aprobatę moralną, jest altruistyczna motywacja. I tutaj jego przekonania moralne znajdują wspólny punkt $z$ metaetycznymi. Za uzasadnione intuicyjnie i indukcyjnie uznał te zasady etyczne, które przyznają wartość, doceniają czy zalecają altruizm i troskę o dobro innych, nawet $\mathrm{z}$ zaniedbaniem własnych potrzeb.

\section{Refleksje i wątpliwości}

Wśród refleksji, do jakich motywują przedstawione poglądy Mariana Przełęckiego, poruszone będą trzy wątki: 1. Trudne związki intuicjonizmu z naturalizmem. 2. Kwestia złudzeń i omylności intuicji moralnej. 3. Miejsce uczuć w racjonalistycznej epistemologii.

Ad 1. Intuicjonizm, także ten Przełęckiego, podziela $\mathrm{z}$ naturalizmem nastawienie kognitywistyczne. Poza tym jednym wspólnym punktem dystansuje się od naturalizmu całkowicie. Naturalizm uważa wartości i/lub powinności za sprowadzalne do empirii, co pozwala mu na empiryczne uzasadnianie etyki (które to nastawienie wytknie jego zwolennikom Hume jako błąd naturalistyczny). Intuicjonizm natomiast przyznaje ocenom wartość poznawczą, a wartościom istnienie obiektywne - lecz tych ostatnich nie szuka pośród empirycznych cech rzeczy. Wartości tworzyć mają sferę autonomiczną względem empirii. Właśnie dlatego dla poznawania ich potrzebna jest inna władza niż zmysły fizyczne, sięgająca w odmienny obszar, a jest to intuicja.

Zbadajmy, jak to się ma do procesu formułowania zasad etycznych w ujęciu Przełęckiego.

Przed sformułowaniem zasady etyk ma wyabstrahować z ocenianych w podobny sposób czynów (niech to będą, powiedzmy, czyny dobre moralnie) ich wspólne cechy, przy czym nie mają to być w żadnym razie cechy definicyjne. Mają to być jedynie cechy przygodne. Przełęcki wskazuje tu na motywację altruistyczną. Uzyskane przez etyka rezultaty mają mieć status zdań empirycznych, odwoływalnych w razie niezgodnych $z$ nimi świadectw. A odwołanie to ma nie naruszać naszych intuicji językowych. Nie dlatego czyny mają budzić u odbiorcy pozytywne uczucia, że są altruistyczne, lecz z bliżej niewyjaśnionych przyczyn, 
altruistyczna zaś motywacja ma tam występować jedynie przygodnie. Na tej podstawie etyk formułuje zasadę etyczną, w myśl której wartościowe moralnie są czyny motywowane altruistycznie.

Nacisk na przygodność i niedefinicyjność cech wspólnych czynom dobrym moralnie, a potrzebnych dla sformułowania zasady, jest zrozumiały w kontekście różnicy między intuicjonizmem a naturalizmem. Gdyby zgodzić się, że altruistyczna motywacja definiuje czyny moralnie dobre - różnica ta stanęłaby pod znakiem zapytania. Altruistyczna motywacja jest bowiem opisową, a nie oceniającą cechą czynu, da się wysłowić w języku psychologicznym i być może jest sprawdzalna empirycznie w drodze odpowiednich testów, na pewno zaś jest sprawdzalna w drodze doświadczenia introspekcyjnego. Dobro moralne, sprowadzone definicyjnie do takiej motywacji, „zjechałoby” rychło do poziomu cech empirycznych, a intuicjonizm, uchodzący powszechnie za odmienny od naturalizmu, okazałby się nieoczekiwanie bardzo naturalizmowi bliski, jeśli nie stanowiący wręcz jakiejś jego odmiany. Stąd podkreślał Przełęcki przygodność cech empirycznych, wspólnych czynom dobrym moralnie i dających podstawę zasadzie.

Ale jeśli istotnie są one przygodne, pociąga to za sobą dwie problematyczne konsekwencje. Po pierwsze, status zasad etycznych zostaje narażony na szwank. Cecha przygodna może przedmiotowi przysługiwać, ale może i nie przysługiwać, nie powodując przez swój brak zamieszania ani w języku, ani w naszej wizji prawidłowości rządzących światem. W opisanej sytuacji zasada etyczna jest nieustannie narażona na odwołanie, i to nie tylko z tych przyczyn, które Przełęcki w swojej metaetyce uwzględnił, i nie przez jakiś błąd w sztuce, lecz ze względu na jeszcze dalej idącą wątłość swych podstaw: wszak każdej chwili może się okazać, że od dziś nasza intuicja wzywa nas do pozytywnej oceny czynów egoistycznych! Zasadę należy wówczas odwołać, i to nie dlatego, że zmienił się świat, wartości czy intuicja, nie dlatego, że intuicja pobłądziła, lecz ot, po prostu dlatego, że takie okazały się przygodne koleje naszej wędrówki poprzez poznanie moralne...

Po drugie, etyka oparta na zasadach odwołujących się do przygodnych cech czynów moralnie dobrych ocierałaby się o irracjonalność. Jeśli czyny te okazują się altruistyczne nie $\mathrm{z}$ istoty rzeczy, wiążącej altruizm $\mathrm{z}$ dobrem moralnym, lecz przygodnie, to nie sposób wyjaśnić, w czym tkwi istota moralnego dobra. Co więcej, nie sposób wyjaśnić tego sięgając do jakichkolwiek innych cech wspólnych czynom dobrym, bo wszelkie takie cechy miałyby być tylko przygodne! Etyka 
staje się wtedy irracjonalna i taka sama staje się intuicja moralna: nie sposób zrozumieć, dlaczego dyktuje nam ona takie, a nie inne oceny, ani co nią kieruje. Pozostaje intuicjoniście tylko ślepe podążanie za jej wezwaniem. I, ewentualnie, formułowanie roboczych zasad o wątpliwym statusie.

Przełęcki był świadom tego słabego punktu intuicjonizmu (o czym autorka wie m.in. $\mathrm{z}$ bezpośrednich $\mathrm{z}$ nim rozmów). $\mathrm{Z}$ jednej strony przyznawał, że uznanie głównej zasady etycznej za definicję dobra moralnego implikowałoby naturalizm, z drugiej jednak w obronie wartości zasad moralnych wspominał przy innych okazjach, że to właśnie w altruizmie tkwi istota dobra moralnego. Inne jego wypowiedzi także wskazują na dystans wobec zadeklarowanej przygodności, dotyczącej współwystępowania altruizmu z dobrem moralnym. Jeśli ma to być tylko przygodne współwystępowanie, dlaczego miarodajność oceny moralnej wymaga, aby oceniający koniecznie znał motywację sprawcy? I jeszcze: wskazując na nieostrość podziału predykatów na opisowe i oceniające, Przełęcki podał przykład predykatu okrutny, który miał znaczyć: nieznający litości (element opisu) $i z$ tej racji zły (element oceny). Odnotujmy w tym kontekście słowa: $z$ tej racji. Czy nie jest tak, że naturalizm, wyrzucony drzwiami, zagląda tu oknem?

Tę ambiwalencję Przełęckiego można próbować interpretować następująco: gdy etyk przystępuje dopiero do refleksji nad jednostkowymi intuicyjnymi ocenami, pojęcie dobra moralnego jest bardzo nieostre i niedoprecyzowane. Jego definicja (zapewne cząstkowa i bardzo ułomna) nie obejmuje jeszcze altruistycznej motywacji. Stopniowo dochodzi etyk do uogólnienia głoszącego, że intuicja kwalifikuje jako dobre moralnie czyny altruistyczne. Im mocniej jest ono potwierdzone, tym łatwiej dojść może do zmiany jego statusu z empirycznego uogólnienia na definicyjną zasadę. (Ajdukiewicz nazywał tego rodzaju zmianę racjonalizacją języka - w procesie tym wzmacnia się treść pojęć w taki sposób, że pewne zagadnienia pierwotnie empiryczne znajdują już rozstrzygnięcie czysto językowe). Pojęcie dobra moralnego miałoby ulec doprecyzowaniu i wzmocnieniu i objąć wskutek tego zabiegu altruizm jako swą cechę definicyjną. Do tego etapu pracy etyka miałyby się odnosić wypowiedzi, włączające cechy empiryczne w treść pojęć wartościujących.

Ale interpretacja taka nie na wiele się zda. Po dokonaniu bowiem wspomnianej racjonalizacji problem naturalizmu wraca z całą mocą. Ujawniają się tu niepożądane przez żadną ze stron związki intuicjonizmu z naturalizmem. 
Tradycyjnie stanowiska te pojmowano jako opozycyjne i wyłączające się. Refleksja nad metaetyką Przełęckiego nasuwa inny obraz, mianowicie - kontinuum stanowisk, gdzie na jednym biegunie występuje skrajny, wolny od domieszek naturalizmu intuicjonizm, na drugim - skrajny, wolny od domieszek intuicjonizmu naturalizm, między nimi zaś - stanowiska pośrednie.

Na pierwszym biegunie mielibyśmy wspomniany już wcześniej intuicjonizm irracjonalny, niewiążący treści żadnych pojęć moralnych z żadnymi cechami empirycznymi. Intuicja byłaby w dużej mierze nieprzewidywalna, a racjonalna etyka znacznie utrudniona. Na drugim biegunie sytuowałby się taki naturalizm, który kompletnie pomija ludzkie odczucia i motywowane uczuciowo przeświadczenia moralne. Definiowalność predykatów oceniających za pomocą predykatów opisowych praktycznie likwiduje tu etykę jako odrębną dyscyplinę, redukując ją do dziedzin empirycznych, z zatraceniem całej jej specyfiki i doniosłości. Czystemu naturalizmowi brakuje podstawy, aby kwalifikować pewne obiekty $\mathrm{z}$ racji ich cech empirycznych jako tak a tak wartościowe. Wartości nie są tu zależne od empirii ani uzasadniane przez nią, lecz zostają wręcz sprowadzone do niej czy przez nią wchłonięte - nie są niczym więcej niż ona. Nie tyle zostaje tu zniesiona autonomia wartości względem empirii, ile raczej w ogóle istnienie wartości różniących się czymkolwiek od cech empirycznych.

Oba te skrajne poglądy wydają się nie do przyjęcia. W poznaniu wartości potrzebne są dwa elementy: znajomość cech ocenianych czynów oraz impuls wartościujący, wzbudzony przez te czyny dlatego, że są one takie właśnie. Impuls ten odnosi się zdecydowanie do czegoś więcej niż naga empiria.

Intuicjonizm potrzebuje szczypty nastawienia naturalistycznego, jeśli intuicja moralna ma być przewidywalna, predykaty oceniające wyposażone w minimum sensu wykraczającego poza werdykty kapryśnej nieraz intuicji, a etyka wolna od chaosu i racjonalna. Naturalizm potrzebuje szczypty nastawienia intuicjonistycznego, jeśli specyfika etyki i jej rola w ludzkim życiu ma być zachowana. Do kognitywisty należy decyzja, jak wyważy proporcje i jakie miejsce znajdzie dla siebie na tle wspomnianego kontinuum. Granica między intuicjonizmem a naturalizmem nie przedstawia się tu jako przepaść nie do przebycia, lecz raczej jako stopniowa zmiana krajobrazu.

Jest jeszcze inny powód, który wskazuje na bliższy związek metaetyki Przełęckiego z naturalizmem, niż widział to sam jej Autor. Intuicję moralną uważał on za aposterioryczną. Zarazem wyrażał przekonanie, że do oceny moralnej czynu 
nie trzeba być jego bezpośrednim świadkiem, bo wystarczy go sobie wyobrazić. Ale przecież wyobraźnia nie wystarcza do rozstrzygania zdań niewątpliwie aposteriorycznych, takich jak np. jelito cienkie człowieka ma długość ponad 4 metry. A tam, gdzie wyobraźnia wystarcza, rozstrzygamy zdania aprioryczne, takie jak np. przekątne kwadratu połowia się. Czy zatem istotnie intuicja moralna miałaby być aposterioryczna? Można wątpić. Skoro może ona działać na podstawie samej wyobraźni - znaczy to, że opiera ocenę moralną na przywołanych w wyobraźni cechach czynu, wraz z całym kontekstem sytuacyjnym. I zapewne sięga do apriorycznie znanych sobie powiązań między tymi cechami i kontekstem $z$ jednej strony, a wartością moralną czynu z drugiej. Innymi słowy, sięga do istoty wartości moralnej, zakorzenionej jakoś w świecie empirii.

Być może uznanie explixite aprioryczności ocen korespondowałoby z modelowaniem poznania moralnego nie według indukcjonistycznego wzorca rozwoju nauki, ale według nowszego wzorca hipotetyczno-dedukcyjnego, uwzględniającego skażenie obserwacji teorią. Od tego jednak Przełęcki był daleki.

Ad 2. Intuicję uważał za omylną, i to w większym stopniu omylną niż zmysły fizyczne (dlatego m.in. relegował etykę poza granice nauki). Niemniej jednak zaproponował intuicjonistyczną teorię złudzeń moralnych, analogiczną do teorii złudzeń zmysłowych, zaburzających poznanie empiryczne. Na czym omylność intuicji moralnej miałaby polegać i skąd się brać, można odczytać $\mathrm{z}$ warunków, jakie - za naturalistami i emotywistami - nałożył na miarodajność intuicyjnej oceny moralnej. Otóż ocena jest miarodajna, gdy wydający ją jest poczytalny, wolny od obciążeń psychicznych, zdolny do koncentracji, bezstronny, niezaangażowany osobiście w sytuację i niemający wpływu na jej rozwój, zdolny do emocjonalnego reagowania, do empatii i do poznawczego uchwycenia wszystkich istotnych cech ocenianej sytuacji, w tym - motywacji sprawcy, wreszcie - abstrahujący w ocenie od faktów nierelewantnych. Nadto ocena ma być zgodna z niesprzecznym i niezbyt skomplikowanym zbiorem zasad ogólnych. Sporadyczną reakcję uczuciową, prowadzącą do postawy niezgodnej z przyjętymi pryncypiami, uważa Przełęcki za analogiczną do ignorowanej zazwyczaj w nauce obserwacji jednostkowej niezgodnej z całokształtem dobrze potwierdzonej teorii.

Ową intuicjonistyczną teorię złudzeń moralnych można rozbudować, wykorzystując dwojakie analogie złudzeń emocjonalnych i zmysłowych.

Zmysły informują nas fałszywie o rzeczywistości w dwojakiego typu sytuacjach. Pierwsza polega na tym, że na interesujące nas wrażenia, na podstawie 
których mamy wydać sąd o tym, co dzieje się w wybranym fragmencie rzeczywistości, nakładają się wrażenia inne, które zaburzają lub zmieniają obraz przedstawiony przez te pierwsze. Wrażenie sumaryczne stanowi jakąś wypadkową ich wszystkich. Najprostszym przykładem jest patrzenie na świat przez ciemne okulary - wszystko wydaje się wtedy przyciemnione. W wypadku uczuć analogiczną sytuację mamy, gdy na uczucie, mające stanowić podstawę do oceny moralnej danej sytuacji, nakłada się uczucie inne, nierelewantne. Może to być wpływające na ocenę osobiste zaangażowanie oceniającego, może to być jego zmęczenie, nieoczekiwanie zaktywizowane jakieś emocjonalne wspomnienie itp.

Pomocna bywa wtedy rozumowa refleksja, czy to w wypadku zmysłów, czy intuicji. Choć genetycznie zmysły są w poznaniu pierwsze, ich sędzią i rozjemcą jest rozum. Podobną rolę może pełnić wobec intuicji moralnych. Wracając do przykładów, można zwyczajnie wziąć pod uwagę, że oglądamy przedmioty przez ciemną przesłonę albo że do oceny czyjegoś postępowania przystąpiliśmy w stanie irytacji - i stosownie do tej wiedzy skorygować nasz ogląd rzeczywistości, starając się pominąć wpływ czynników ubocznych. Z Przełęckiego teorii złudzeń moralnych skorzystać można nie tylko po to, aby wiedzieć, jakie to uboczne czynniki powinny być przy wydawaniu oceny nieobecne, lecz - nieco realistyczniej - także po to, aby w sytuacji, w której czynniki te są nieuniknione, umieć je zidentyfikować, rozpoznać ich niepożądany wpływ i spróbować go zneutralizować.

Ale jest jeszcze drugi typ sytuacji, w których zmysły zwodzą. Wrażenie, na podstawie którego opisujemy jakiś fragment rzeczywistości, nie zostaje zakłócone przez inne, uboczne wrażenia, które miałyby się na tamto nałożyć, zostaje natomiast mylnie zinterpretowane i dlatego opis może być fałszywy. Tak jest, gdy zmysł działa wadliwie - na przykład, zgodnie z wrażeniami krótkowidza pewien napis jawi się jako rozmazany, choć wcale taki nie jest. Tak jest również, gdy sytuacja jest nietypowa - na przykład w wypadku włożonego do wody kija, który wydaje się złamany. Remedium w obu wypadkach stanowi oczywiście reinterpretacja danych zmysłowych. Aby to się stało, potrzebna jest refleksja rozumowa, angażująca pewnego rodzaju „teorię”, odmienną od „teorii”, w ramach której zwykliśmy interpretować dane zmysłowe bezrefleksyjnie i niemal automatycznie. Natychmiast nasuwa się skojarzenie z teoretycznym skażeniem obserwacji, którego to wątku Przełęcki w swojej logice nauk empirycznych nie wykorzystał. W nauce - im mocniej są obserwacje skażone teoretycznie, tym łatwiej 
pojawia się potrzeba odwołania zdań, zdających z nich sprawę. W życiu potocznym - analogicznie, im więcej założeń obejmuje zdroworozsądkowa „teoria”, do której odnosimy wrażenia, tym łatwiej o potrzebę reinterpretacji tych wrażeń. W skrajnym wypadku żadnych takich założeń nie ma - i wtedy z wrażeń zdaje sprawę tylko język fenomenalistyczny, niemówiący niczego o zewnętrznej rzeczywistości.

Opisana sytuacja znajduje swój odpowiednik na gruncie bezpośredniego poznania moralnego. Uczucia, tak jak i zmysły, mogą fałszywie informować o rzeczywistości. W myśl tzw. dwuczynnikowej teorii emocji, sformułowanej przez S. Schachtera i J. Singera, na emocję składa się po pierwsze - fizjologiczne pobudzenie ciała i zwykle zaaktywizowana wówczas dyspozycja do działania, a po drugie - interpretacja tego pobudzenia. Otóż zdarza się, że ta interpretacja jest fałszywa. Pobudzenie zostaje złożone na karb innej przyczyny niż ta, która je faktycznie wywołała. A ponieważ intuicyjna ocena kieruje się ku przedmiotowi, który w przekonaniu oceniającego miał wywołać pozytywne lub negatywne wrażenia, ocenę tę zbiera domniemana, lecz nietrafnie zidentyfikowana przyczyna! Pierwszy komponent uczucia - pobudzenie - nie podlega dyskusji, nie da się go negować, ale też nie może sam w sobie być nośnikiem fałszu. Analogiczny jest do czystych wrażeń zmysłowych, z których zdaje sprawę język fenomenalistyczny. Zdania wygłoszone w takim języku, jeśli tylko są szczere, nie mogą być fałszywe. Za to drugi komponent uczucia - interpretacja pobudzenia - może być nośnikiem fałszu. Jeśli tak się dzieje, można powiedzieć, że uczucie jest fałszywe.

Liczne teorie emocji można uporządkować według tego, jak ważką rolę przydają komponentowi poznawczemu uczuć. W uproszczeniu przyjmuje się podział dychotomiczny na uczucia epistemiczne i nieepistemiczne. W istocie teorie emocji tworzą pewne kontinuum, biorąc pod lupę różnego typu uczucia, a te bywają w różnym stopniu epistemiczne. Na jednym biegunie mamy wśród uczuć czyste pobudzenia ciała $\mathrm{w}$ reakcji na bodźce. Tak jak i czyste wrażenia, nie są odnoszone do swego zewnętrznego źródła. Na przeciwnym biegunie mamy wyraźne sądy wartościujące, wsparte odczuciami, ale i może pamięcią, uprzednio przyjętymi zasadami itp. Im bardziej epistemiczne uczucie, tym większa w nim rola myśli i tym mocniej pobudzenie ciała wiązane jest $\mathrm{w}$ myślach $\mathrm{z}$ zewnętrznymi przedmiotami czy zdarzeniami, mającymi to pobudzenie wywołać. A wartościujący sąd dotyczy wtedy tych właśnie przedmiotów czy zdarzeń. Interpretacja pobudzenia analogiczna jest do teorii, powodującej skażenie obserwacji. Można 
powiedzieć, że uczucia epistemiczne „skażone” są komponentem myślowym. Im więcej miejsca zajmuje w uczuciu interpretacja pobudzenia, tym łatwiej o ewentualną tego uczucia fałszywość czy złudność. Ciekawe, że Przełęcki w filozofii nauki pomijał skażenie teoretyczne obserwacji, natomiast w filozofii moralnej pojmował uczucia jako zdecydowanie epistemiczne, o aksjologicznych walorach poznawczych.

Znajomość mechanizmów, powodujących zwodnicze działanie zmysłu moralnego, jest pierwszym krokiem do prób kontrolowania i ewentualnie korygowania jego pracy. Przełęckiego teorię złudzeń moralnych owocnie uzupełnić może wspomniana dwuczynnikowa teoria emocji.

Ad 3. W poprzednim punkcie rozum jawi się jako interpretator, kontroler i sędzia zarówno wrażeń zmysłowych, jak i impulsów emocjonalnych. Należy do niego w szczególności ocena komponentów poznawczych jednych i drugich. Rozum bierze pod uwagę wrażenia zmysłowe i emocjonalne i dokonuje refleksji nad najprostszym, narzucającym się niemal automatycznie sposobem, w jaki skłonni jesteśmy te wrażenia (jedne i drugie) sobie tłumaczyć i wydawać na ich podstawie sądy o rzeczywistości. Czasem krytycznie ocenia tę pierwszą interpretację i uchyla ją, przyjmując w zamian inną, która odmiennie przedstawia rzeczywistość.

O tym, że rozum taką rolę wobec zmysłów wypełnia, wiadomo w filozofii od kilku stuleci. U progu nowożytności empiryzm konfrontował się z wąsko pojętym racjonalizmem, który przeciwstawiał poznanie myślowe doświadczalnemu, podnosząc walory pierwszego i mankamenty drugiego, a w konsekwencji przedkładając pierwsze nad drugie. W rezultacie tej konfrontacji racjonalizm - który wszak potrzebuje do rozumowań jakichś przesłanek wyjściowych, ale sam ich sobie nie dostarczy - wchłonął z czasem empiryzm, przekształcając się do postaci tzw. racjonalizmu szerokiego, sankcjonującego empiryczną bazę poznania. Choć $\mathrm{w}$ granicach tego szerokiego racjonalizmu genetycznie pierwsze są $\mathrm{w}$ poznaniu zmysły, jednak rozum pozostaje nadrzędną władzą poznawczą, gdyż kontroluje całość procesu poznawczego, jest rozjemcą zmysłów w razie ich konfliktu, ocenia ich wiarygodność i dostarczony przez nie materiał i ustala jego interpretację, niekiedy wybierając krytycznie spośród różnych możliwości. Tak, o tym wiadomo od dawna.

Natomiast uczucia pozostawały poza tą rozumowo-empiryczną symbiozą, tworzącą podstawę metody naukowej. A przecież opozycja między poznaniem naukowym a intuicyjnym czy uczuciowym przypomina bardzo dawną opozycję 
miedzy wąskim racjonalizmem a empiryzmem. I można spodziewać się podobnego przezwyciężenia obecnej opozycji. Otóż rozum, nawet wsparty o poznanie empiryczne, nie ma skąd zaczerpnąć przesłanek do wyznaczania autotelicznych celów ludzkiej działalności (podobnie jak ongiś, odżegnując się od poznania doświadczalnego, nie miał skąd zaczerpnąć przesłanek dla poznawania otaczającego nas świata). Cele instrumentalne można bowiem wyznaczać racjonalnie ze względu na to, czy stanowią skuteczne środki do realizacji celów nadrzędnych. Ale co z celami najwyższymi, których już do niczego ponad nimi samymi odnieść nie można? Czy ich wybór ma być irracjonalny?

Wyborowi celów autotelicznych czy najwyższych wartości uzasadnienia dostarczyć może właśnie intuicja czy nasze reakcje uczuciowe. Rozum może albo odżegnywać się od nich (tak jak kiedyś odżegnywał się od świadectw zmysłowych jako od zawodnych, niepewnych i mniej doskonałych niż świadectwa rozu$\mathrm{mu}$ ), albo rozciągnąć nad nimi swego rodzaju patronat, zwierzchność i kontrolę (znowu - jak kiedyś nad poznaniem empirycznym), włączając je w obszar swoich dociekań. Byłby to kolejny krok w poszerzaniu racjonalizmu u jego genetycznych podstaw o przesłanki jeszcze mniej pewne niż poprzednio, ale z wypełnieniem ważnej luki poznawczej, której wypełnienie w inny sposób byłoby co najmniej trudne, jeśli nie niemożliwe.

$\mathrm{W}$ podobnym kierunku idzie W. Jamesa model rozszerzonej racjonalności. Racjonalność przekonań zależy tam nie tylko od świadectw empirycznych i ich myślowej obróbki, ale także - od spodziewanych skutków przyjęcia tych przekonań. Oczywiście, w pierwszym rzędzie ważyć mają świadectwa, lecz wobec ich braku racjonalnie jest uznać przekonanie, które np. pociągnie za sobą motywacje do pożądanych działań, zakorzenione w określonej wizji świata. Modelowi Jamesa bliska jest koncepcja racjonalności uwzględniającej intuicję. Znajdujemy ją właśnie u Przełęckiego, który (już poza kontekstem metaetycznym) odróżnił racjonalność logiczną od pragmatycznej. Ta pierwsza zależeć ma od uzasadnienia przekonań, a druga od ich praktycznego znaczenia dla naszego życia, od ich związku z naszymi uczuciami, nadziejami i postawami.

Intuicji i uczuć potrzebuje rozum nie tylko dla uzasadnienia najwyższych celów czy wartości. Potrzebuje ich do sprawy jeszcze bardziej podstawowej niż ta, do której potrzebuje przesłanek empirycznych. Mianowicie - do ukształtowania języka. U podstaw języka leży bowiem ustrukturowane w jakiś sposób widzenie rzeczywistości. Struktura ta powstaje $\mathrm{z}$ wyodrębnienia obiektów i zdarzeń z potoku wrażeń oraz z łączenia ich w klasy. Podstawą tego ostatniego zabiegu 
są owocujące później powstaniem nazw ogólnych tzw. standardy podobieństwa. Mogą one być różne, w zależności od elementarnych potrzeb społeczności oraz od wagi, jaką przydaje ona różnym fragmentom zewnętrznej rzeczywistości i różnym swoim z nią interakcjom. A potrzeby, poczucie ważności spraw, ukierunkowanie uwagi - to już jest ten obszar, w którym operują impulsy, uczucia i intuicja. Były i są niezbędne do tego, abyśmy nie żyli w chaosie nieuporządkowanych wrażeń, aby świat nasz był intelligibilny i abyśmy mogli się między sobą na jego temat komunikować.

Rysuje się na tej podstawie pewne kontinuum władz poznawczych, gdzie na jednym biegunie mamy rozum (nadrzędny, najmniej narażony na błędy, najmniej samowystarczalny, potrzebujący niezbędnego genetycznego wsparcia od innych władz). Na przeciwnym biegunie - intuicja i uczucia, z włączeniem impulsów, potrzeb, selektywności uwagi, poczuciem ważności spraw (najbardziej narażone na błędy, szczególnie wymagające rozumowej kontroli, ale w podstawowym sensie genetycznie pierwsze w poznaniu werbalnym). A pośrodku - zmysły dostarczające wiedzy empirycznej (bardziej zawodne niż rozum, ale nie tak bardzo, jak intuicja; wymagające kontroli ze strony rozumu, lecz niezbyt usilnej; dostarczające przesłanek dla pracy rozumu nad kształtowaniem ogólnej wiedzy empirycznej, lecz zarazem opierające się na pewnych rezultatach działania intuicji).

Metaetyka Przełęckiego, z uwzględnieniem jej ewentualnych a zaproponowanych tutaj uzupełnień, idzie dokładnie w kierunku kolejnego kroku w poszerzeniu racjonalizmu do postaci obejmującej także intuicję. Dla zaznaczenia szczególnej zawodności intuicji sytuuje aksjologię w obszarze dociekań racjonalnych, choć nienaukowych. Ciekawe, że rozum, czy sankcjonuje poznanie empiryczne (resp. uczuciowe), czy nie, genetycznie zawsze się na nim (jednym i drugim) niechybnie opiera. Owo „poszerzanie” zatem to tylko usankcjonowanie stanu faktycznego.

\section{Bibliografia}

Ajdukiewicz K., Obraz świata i aparatura pojęciowa, w: tegoż, Język i poznanie, t. I, Wybór pism z lat 1920-1939, PWN, Warszawa 1985.

Ajdukiewicz K., Postępowanie człowieka, w: tegoż, Język i poznanie, t. I, Wybór pism z lat 1920-1939, PWN, Warszawa 1985. 
Elzenberg H., Intuicja, w: Materialy Henryka Elzenberga zebrane w Archiwum Polskiej Akademii Nauk, sygn. III-181-95, 1940.

Elzenberg H., Epistemologia wartości. Wykłady 1949-1950, w: tegoż, Pisma aksjologiczne, Wyd. UMCS, Lublin 2002.

James W., Prawo do wiary, tłum. A. Grobler, Wyd. Znak, Kraków 1996.

Neurobiology of Human Values, J.-P. Changeux, A. Damasio, W. Singer (eds.), Springer, Berlin 2005.

Przełęcki M., Logika nauk empirycznych, tłum. z ang. J.E. Jasińska, PWN, Warszawa 1988.

Przełęcki M., Chrześcijaństwo niewierzących, Czytelnik, Warszawa 1989.

Przełęcki M., Poza granicami nauki, Znak-Język-Rzeczywistość, Polskie Towarzystwo Semiotyczne, Warszawa 1996.

Przełęcki M., O pewnych filozoficznych konsekwencjach semantycznej definicji prawdy, „Studia Filozoficzne” 1973, nr 6(91).

Przełęcki M., O rozumności i dobroci, Wydawnictwo Naukowe Semper, Warszawa 2002.

Przełęcki M., Sens i prawda w etyce, Znak-Język-Rzeczywistość, Polskie Towarzystwo Semiotyczne, Warszawa 2004.

Przełęcki M., Intuicje moralne, Wydawnictwo Naukowe Semper, Warszawa 2005. Przełęcki M., Horyzonty metafizyki, Wydawnictwo Naukowe Semper, Warszawa 2007.

Schachter S., Singer J., Cognitive Social and Physiological Determinants of Emotional State, „Psychological Rewiev” Sept. 1962 (69), s. 379-399.

\section{Streszczenie}

Choć Marian Przełęcki uważał poznanie moralne za nienaukowe, poglądy na nie modelował według swoich wcześniejszych poglądów na poznanie w naukach empirycznych. Nauka wychodzi od zdań jednostkowych, opartych na poznaniu zmysłowym i doświadczeniu, a następnie je indukcyjnie uogólnia, dochodząc do zasad. Poznanie moralne zaś wychodzi od jednostkowych ocen, których źródłem jest intuicja czy zmysł moralny, po czym uogólnia je indukcyjnie do postaci zasad etycznych. Swoje stanowisko metaetyczne nazwał zatem indukcjonistycz- 
nym intuicjonizmem. Niniejszy tekst przedstawia trzy refleksje, do jakich motywuje przemyślenie tego stanowiska: 1 . Granica między intuicjonizmem a naturalizmem jest nieostra. Co więcej, wbrew rozpowszechnionemu przekonaniu i przekonaniu samego Przełęckiego, każde $\mathrm{z}$ tych stanowisk musi zawierać jakąś przymieszkę drugiego. 2. Istnieją pewne interesujące analogie (wykraczające poza projekt Przełęckiego) między złudzeniami zmysłowymi a złudzeniami intuicji moralnej. 3. A także analogie, dotyczące relacji, w jakie rozum wchodzi $\mathrm{z}$ jednej strony $\mathrm{z}$ poznaniem zmysłowym, a $\mathrm{z}$ drugiej $-\mathrm{z}$ intuicyjnym poznaniem moralnym.

Słowa kluczowe: indukcjonizm, intuicjonizm, metaetyka, naturalizm, Przełęcki, zasada etyczna

\section{Summary}

\section{Reflections on Marian Przełęcki's Metaethical Intuitionism}

Although Marian Przełęcki considered moral cognition as non-scientific, he shaped his views on its sources and structure according to his earlier views on cognition in natural sciences. The starting point in the latter are individual sentences based on experience and sensual cognition, which are then generalized as empirical principles or laws. On the other hand, the starting point in moral cognition are individual assessments rooted in intuition or moral sense, next generalized inductively as moral principles. Therefore, Przełęcki named his metaethical views an inductive intuitionism. The paper presents three reflections evoked by those views: 1 . In metaethics, the border between intuitionism and naturalism is vague. Moreover, in spite of the common view and Przełęcki's conviction, each of those two concepts must include an admixture of the other. 2. There are some interesting analogies (going beyond Przełecki's project) between sensual illusions and moral-sense illusions. 3. As well as there exist analogies dealing with the relations between the reason and, on the one hand, empirical cognition, and on the other hand, intuitive moral cognition.

Key words: inductionism, intuitionism, metaethics, moral principle, naturalism, Przełęcki. 